\title{
A Second Look at the U.S. Great Depression from a Neoclassical Perspective
}

\author{
Harold L. Cole and Lee E. Ohanian
}

Between 1929 and 1933 in the United States, employment fell about 25 percent and output fell about 30 percent. By 1939, employment and output remained well below their 1929 levels. Why did employment and output fall so much in the early 1930s? Why did they remain so low a decade after the contraction began?

This paper addresses these two questions about the Great Depression using neoclassical growth theory. By neoclassical growth theory, we mean the theory that Cass (1965) and Koopmans (1965) set out, augmented with theory about certain shocks that cause employment and output to deviate from their deterministic growth paths, as Kydland and Prescott (1982) discussed. ${ }^{1}$ Traditionally, growth theory has not been used to study depressions, and in the past it probably would have been considered bizarre to use a marketclearing framework to analyze episodes that seemed to defy an equilibrium explanation. Our view is that growth theory can significantly advance our understanding of depressions by systematically assessing which data are consistent with the theory and which observations are puzzling. We therefore analyze both the decline in U.S. economic activity (1929-33) and the recovery from the Depression (1934-39) using the same analytical framework. This analysis draws on our 1999 paper (Cole and Ohanian 1999), and also includes discussions of subsequent analyses.

We focus our analysis on the shocks that could plausibly account for the large declines in output and employment between 1929 and 1939. Since the Depression was much more severe and lasted so much longer than an ordinary business cycle, the shocks that caused the Depression must have differed significantly from the shocks that drive postwar business cycles. One possibility is that the shocks that caused the Depression were much larger and more persistent versions of the same shocks that cause postwar 
fluctuations. An alternative possibility is that the shocks that caused the Depression were fundamentally different from the shocks that cause postwar fluctuations.

We evaluate these two possibilities by testing whether the shocks that are considered important for understanding normal business cycle fluctuations - productivity shocks, fiscal policy shocks, trade shocks, monetary policy shocks, and financial intermediation shocks - quantitatively account for macroeconomic activity during the 1930s. Our two main findings are surprising. The first is that productivity shocks - even after correcting for possible input mismeasurement and compositional shifts - may account for over half of the 1929-33 downturn. The second finding is that none of the shocks we consider can plausibly account for the weak recovery. Growth theory robustly predicts that employment and output should have returned to their normal levels by the late 1930s because most of the shocks we consider become large and positive after 1933 . The weak recovery is a major puzzle from the perspective of neoclassical theory.

We then search for clues to this puzzle by examining deviations in the first-order conditions of the model. Large deviations in these conditions shed light on the factors that prevented a full recovery by telling us what dimensions of the model are significantly at variance with the data. We conduct this deviation analysis first by parameterizing the model so that all the firstorder conditions in the model are satisfied in 1929, and then by measuring the deviations in these conditions in 1939. This analysis shows that a labor market distortion that raised the real wage above its competitive level is a leading candidate explanation of the weak recovery. This is because the real wage is more than 20 percent above its normal level and also is more than 20 percent above the marginal product of labor, and is more than 100 percent above the household's marginal rate of substitution (MRS) between consumption and leisure.

An abnormally high real wage suggests a noncompetitive explanation because normal competitive forces should have reduced the real wage and increased employment and consumption. We conclude our study by summarizing our recent work (Cole and Ohanian 2004) that argues that President Roosevelt's noncompetitive policies that raised real wages and sanctioned monopoly account for about 60 percent of the weak recovery. Roosevelt's National Industrial Recovery Act of 1933 allowed much of the economy to cartelize, provided that industry immediately raise wages and engage in collective bargaining with independent labor unions, and the National Labor Relations Act of 1935 significantly increased labor bargaining power. These policies fostered cartelization, high real wages, and the inability of households to equate their MRS with the real wage. 


\section{The Data through the Lens of Theory}

We begin our study by using growth theory to examine some key macroeconomic variables during the 1930s. Neoclassical growth theory has two cornerstones: the aggregate production technology, which describes how labor and capital services are combined to create output, and the willingness and ability of households to substitute commodities over time, which govern how households allocate their time between market and nonmarket activities and how they allocate their income between consumption and savings. Viewed through the lens of this theory, the key variables are the allocation of output between consumption and investment, the allocation of time (labor input) between market and nonmarket activities, and the productivity of capital and labor. ${ }^{2}$

\section{Output}

Table 1 shows consumption, investment, and the other components of real gross national product (GNP) for the 1930-39 period. ${ }^{3}$ Since the theory indicates that these variables can be expected to grow, on average, at the trend rate of technology, they are also detrended, that is, adjusted for trend growth. ${ }^{4}$ With these adjustments, the data can be directly compared to their peak values in 1929. Note that we do not follow the standard business cycle detrending procedure of Hodrick and Prescott (1997). This is because the standard parameterization of the H-P filter procedure focuses on measuring much shorter fluctuations, such as post-World War II U.S. fluctuations, and consequently would treat much of the Great Depression as a change in the

Table 1. Consumption, investment, and other components of GNP, 1930-39

\begin{tabular}{lccccccc}
\hline & & \multicolumn{2}{c}{ Consumption } & Investment & Government & \multicolumn{2}{c}{ Foreign trade } \\
\cline { 3 - 4 } \cline { 6 - 7 } Year & Real GNP & Durables & Nondurables & nonresidential & purchases & Exports & Imports \\
\hline 1930 & 87.4 & 76.2 & 90.9 & 79.2 & 105.1 & 85.3 & 84.9 \\
1931 & 78.1 & 63.4 & 85.4 & 49.4 & 105.4 & 70.6 & 72.4 \\
1932 & 65.2 & 46.7 & 76.0 & 27.9 & 97.3 & 54.5 & 58.1 \\
1933 & 61.9 & 44.4 & 72.2 & 24.6 & 91.7 & 52.8 & 60.8 \\
1934 & 64.6 & 49.0 & 72.1 & 28.4 & 101.1 & 52.8 & 58.3 \\
1935 & 68.1 & 58.9 & 73.1 & 34.4 & 100.1 & 53.8 & 69.3 \\
1936 & 74.9 & 70.8 & 77.0 & 45.9 & 113.9 & 55.1 & 71.9 \\
1937 & 76.0 & 72.2 & 77.2 & 53.6 & 106.3 & 64.3 & 78.3 \\
1938 & 70.6 & 56.3 & 74.3 & 37.8 & 112.0 & 62.8 & 58.6 \\
1939 & 73.5 & 64.3 & 75.0 & 40.5 & 112.9 & 61.7 & 61.6 \\
\hline
\end{tabular}


trend, rather than as a deviation from trend.

Table 1 shows that all the components of real output (in base-year prices), except government purchases of goods and services, fell considerably during the 1930s. The general pattern is a very large drop between 1929 and 1933, followed by only a small rise from the 1933 trough. Output fell more than 38 percent between 1929 and 1933. By 1939, output remained nearly 27 percent below its 1929 detrended level. This detrended decline of 27 percent consists of a raw 11 percent drop in per capita output and a further 16 percent drop representing trend growth that normally would have occurred over the 1929-39 period. $^{5}$

The largest decline occurred in business investment, which fell nearly 80 percent between 1929 and 1933. Consumer durables, which represent household (as opposed to business) investment, followed a similar pattern, declining more than 55 percent between 1929 and 1933. Consumption of nondurables and services declined almost 29 percent between 1929 and 1933. Foreign trade (exports and imports) also fell considerably between 1929 and 1933. The impact of the decline between 1929 and 1933 on government purchases was relatively mild, and government spending even rose above its trend level in 1930 and 1931.

Table 1 also establishes that the economy did not recover much from the 1929-33 decline. In 1933, consumption of nondurables and services was about 28 percent below its 1929 detrended level and remained about 25 percent below this level in 1939. Business investment remained 59 percent below its 1929 detrended level in 1939, and consumer durables remained 36 percent below their 1929 detrended level in 1939. The lack of recovery in

Figure 1. Detrended levels of output and consumption, 1929-39

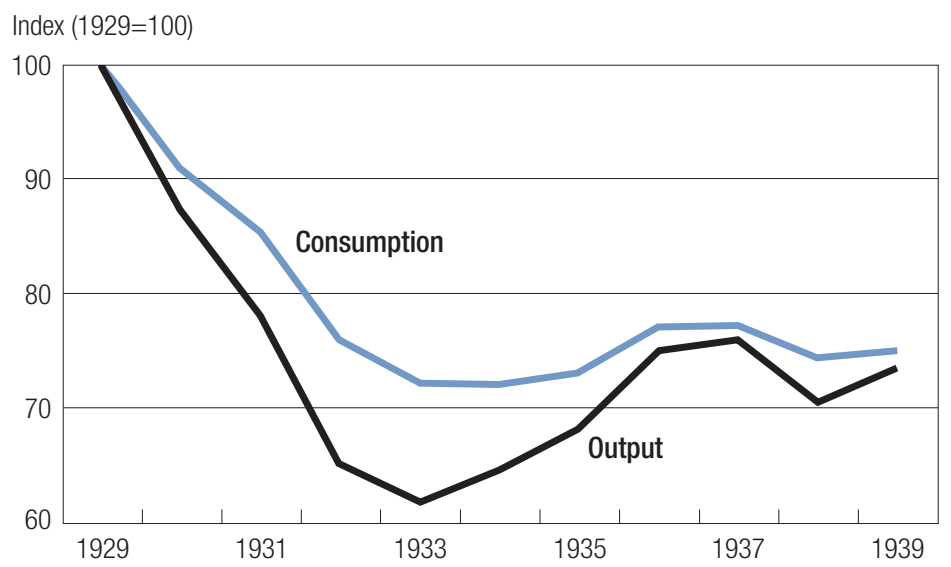


Table 2. Changes in composition of output, 1929-39

\begin{tabular}{lccccc}
\hline \multicolumn{9}{c}{ Shares of output } & & \\
\hline & & Government & & \multicolumn{2}{c}{ Foreign trade } \\
\cline { 3 - 6 } Year & Consumption & purchases & Investment & Exports & Imports \\
\hline 1929 & 0.62 & 0.13 & 0.25 & 0.05 & 0.04 \\
1930 & 0.64 & 0.16 & 0.19 & 0.05 & 0.04 \\
1931 & 0.67 & 0.18 & 0.15 & 0.04 & 0.04 \\
1932 & 0.72 & 0.19 & 0.08 & 0.04 & 0.04 \\
1933 & 0.72 & 0.19 & 0.09 & 0.04 & 0.04 \\
1934 & 0.69 & 0.20 & 0.11 & 0.04 & 0.04 \\
1935 & 0.66 & 0.19 & 0.15 & 0.04 & 0.04 \\
1936 & 0.63 & 0.20 & 0.17 & 0.04 & 0.04 \\
1937 & 0.63 & 0.18 & 0.19 & 0.04 & 0.04 \\
1938 & 0.65 & 0.21 & 0.14 & 0.04 & 0.04 \\
1939 & 0.63 & 0.20 & 0.16 & 0.04 & 0.04 \\
\hline
\end{tabular}

Source: U.S. Department of Commerce, Bureau of Economic Analysis.

consumption, combined with persistently low levels of investment, suggests the possibility that the economy was converging to a new, lower, steady-state growth path. Consumption is a good barometer of a change in the economy's steady state because household dynamic optimization implies that all future expectations of income should be factored into current consumption decisions. ${ }^{6}$ Figure 1 clearly shows the flat time profile of consumption after the Depression trough in 1933.

These unique and large changes in economic activity during the Depression also changed the composition of output - the shares of output devoted to consumption, investment, government purchases, and exports and imports. Table 2 shows these data. The share of output consumed rose considerably during the early 1930s, while the share of output invested, including consumer durables, declined sharply, falling from 25 percent in 1929 to just 8 percent in 1932. During the 1934-39 recovery, the share of output devoted to investment averaged about 15 percent, compared to its postwar average of 20 percent. This low rate of investment led to a decline in the capital stock - the gross stock of fixed reproducible private capital declined more than 6 percent between 1929 and 1939, representing a decline of more than 25 percent relative to trend. Foreign trade comprised a small share of economic activity in the United States during the 1929-39 period. Both exports and imports accounted for about 4 percent of output during the decade. The increase in government purchases, combined with the decrease in output, increased the government's share of output from 13 percent to about 20 percent by 1939 . 
We now turn from final expenditure to productive inputs and the efficiency of production.

\section{Labor Input}

Data on labor input are presented in Table 3. We present five measures of labor input, each divided by the working-age population. We do not detrend these ratios because theory implies that they will be constant along the steady-state growth path. ${ }^{7}$ Here, again, data are expressed relative to their 1929 values.

The three aggregate measures of labor input declined sharply from 1929 to 1933. Total employment, which consists of private and government workers, declined about 21 percent between 1929 and 1933 and remained 13 percent below its 1929 level in 1939. Total hours, which reflect changes in employment and changes in hours per worker, declined more sharply than total employment, and the trough did not occur until 1934. Total hours remained 21 percent below their 1929 level in 1939. Private hours, which do not include the hours of government workers, declined more sharply than total hours, reflecting the fact that government employment did not fall during the 1930s. Private hours fell more than 25 percent between 1929 and 1939.

These large declines in aggregate labor input reflect different changes across sectors of the economy. Farm hours and manufacturing hours are shown in the last two columns of Table 3 . In addition to being divided by the working-age population, the farm hours measure is adjusted for an annual secular decline in farm employment of about 1.8 percent per year. In contrast

\section{Table 3. Five measures of labor input, divided by working-age population, 1930-39}

\begin{tabular}{lcccrrr}
\hline & \multicolumn{3}{c}{ Aggregate measures } & & \multicolumn{2}{c}{ Sectoral measures } \\
\cline { 2 - 3 } Year & $\begin{array}{c}\text { Total } \\
\text { employment }\end{array}$ & $\begin{array}{c}\text { Total } \\
\text { hours }\end{array}$ & $\begin{array}{c}\text { Private } \\
\text { hours }\end{array}$ & & $\begin{array}{c}\text { Farm } \\
\text { hours }\end{array}$ & $\begin{array}{c}\text { Manufacturing } \\
\text { hours }\end{array}$ \\
\hline 1930 & 93.8 & 92.0 & 91.5 & 99.0 & 83.5 \\
1931 & 86.7 & 83.6 & 82.8 & & 101.6 & 67.2 \\
1932 & 78.9 & 73.5 & 72.4 & & 98.6 & 53.0 \\
1933 & 78.6 & 72.7 & 70.8 & & 98.8 & 56.1 \\
1934 & 83.7 & 71.8 & 68.7 & & 89.1 & 58.4 \\
1935 & 85.4 & 74.8 & 71.4 & 93.1 & 64.8 \\
1936 & 89.8 & 80.7 & 75.8 & 90.9 & 74.2 \\
1937 & 90.8 & 83.1 & 79.5 & 98.8 & 79.3 \\
1938 & 86.1 & 76.4 & 71.7 & & 92.4 & 62.3 \\
1939 & 87.5 & 78.8 & 74.4 & 93.2 & 71.2 \\
\hline
\end{tabular}


to the other measures of labor input, farm hours remained near trend during much of the decade. Farm hours were virtually unchanged between 1929 and 1933 , a period in which hours worked in other sectors fell sharply. Farm hours did fall about 10 percent in 1934 and were about 7 percent below their 1929 level by 1939. A very different picture emerges for manufacturing hours, which plummeted more than 40 percent between 1929 and 1933 and remained 29 percent below their detrended 1929 level at the end of the decade.

These data raise questions about differences between the farm and manufacturing sectors during the Depression. Why did farm hours not decline more during the Depression? Why did manufacturing hours decline so much? We will return to these questions later.

Finally, note that the changes in nonfarm labor are similar to changes in consumption during the 1930s. After falling sharply between 1929 and 1933, labor remained well below 1929 levels in 1939. These data also suggest that the economy was converging to a lower steady-state growth path than the 1929 growth path.

\section{Productivity}

Table 4 shows three measures of productivity: labor productivity (output per hour) and total factor productivity (TFP) for both the private domestic economy and the private nonfarm economy. These measures are detrended and expressed relative to 1929 measures. All three series show similar changes during the 1930s. Labor productivity and both measures of TFP declined sharply in 1932 and 1933, falling about 12 percent, 13 percent, and 16 per-

Table 4. Three measures of productivity, 1930-39

\begin{tabular}{lccc}
\hline & & \multicolumn{2}{c}{ TFP } \\
\cline { 3 - 4 } Year & GNP/hour & $\begin{array}{c}\text { Private } \\
\text { domestic }\end{array}$ & $\begin{array}{c}\text { Private } \\
\text { nonfarm }\end{array}$ \\
\hline 1930 & 95.3 & 94.8 & 94.8 \\
1931 & 95.2 & 93.4 & 92.0 \\
1932 & 89.4 & 87.6 & 85.8 \\
1933 & 84.8 & 85.7 & 82.7 \\
1934 & 90.3 & 93.1 & 92.7 \\
1935 & 94.8 & 96.3 & 95.3 \\
1936 & 93.7 & 99.5 & 99.5 \\
1937 & 95.1 & 100.1 & 99.3 \\
1938 & 94.6 & 99.9 & 98.1 \\
1939 & 95.2 & 102.6 & 100.1 \\
\hline
\end{tabular}


cent, respectively, below their 1929 detrended levels. After 1933, however, all three measures rose quickly relative to trend and, in fact, returned to trend by 1936 . When we compare 1939 data to 1929 data, we see that the 1930 s were a decade of normal productivity growth. Labor productivity grew more than 22 percent between 1929 and 1939, and both measures of TFP grew more than 20 percent in the same period. These data also suggest that the economy should have returned to its original steady-state growth path, rather than settling on a lower growth path.

An alternative interpretation of the weak recovery is that recoveries are naturally slow. Table 5 assesses whether there is empirical support for this alternative view by showing average detrended levels of output, consumption, and investment in postwar recoveries. The data are reported relative to the respective business cycle peak and are measured from the trough. These data do not support this alternative view. A comparison of Tables 1 and 5 shows that the recovery from a typical postwar recession differs considerably from the 1934-39 recovery. First, output rapidly recovers to trend following a typical postwar recession. Second, consumption grows smoothly following a typical postwar recession. This contrasts with the flat time path of consumption during the 1934-39 recovery. Third, investment recovers to trend following a typical postwar recession. During the Depression, however, the recovery in investment was much slower, remaining well below the recovery in output.

These data show that the 1934-39 recovery was quantitatively and qualitatively different from the recovery from a typical postwar recession. This is also consistent with the view that the economy was not returning to its pre-1929 steady-state growth path, but was settling on a considerably lower steady-state growth path.

We now compare the U.S. Depression to depressions in other countries that occurred at the same time. This comparison also suggests that the United States should have recovered much more quickly than it actually did.

Table 5. Detrended output and components in typical postwar recovery

\begin{tabular}{ccccc}
\hline $\begin{array}{c}\text { Quarters from } \\
\text { trough }\end{array}$ & Output & Consumption & Investment & $\begin{array}{c}\text { Government } \\
\text { purchases }\end{array}$ \\
\hline 0 & 96.8 & 99.0 & 92.7 & 99.5 \\
1 & 97.8 & 99.4 & 93.9 & 98.4 \\
2 & 98.6 & 99.4 & 96.1 & 98.6 \\
3 & 99.3 & 99.5 & 98.4 & 98.0 \\
4 & 100.1 & 99.7 & 99.7 & 98.1 \\
\hline
\end{tabular}

Source: U.S. Department of Commerce, Bureau of Economic Analysis.

Note: Data measured quarterly from trough; peak $=100$; H-P filtered detrending. 


\section{An International Comparison}

How much of the U.S. Great Depression was caused by international shocks rather than domestic shocks? We suspect that most of the Depression was due to domestic shocks. Many countries suffered economic declines during the 1930s, but there are two important distinctions between the U.S. Depression and depressions in other countries during the 1930s. The decline in the United States was much more severe, and the recovery from the decline was much weaker. To see this, we examine average real per capita output relative to its 1929 level for Belgium, Britain, France, Germany, Italy, Japan, and Sweden. Since there is some debate over the long-run growth rate in some of these countries, we have not detrended the data.

Table 6 shows the U.S. data and the mean of the normalized data for other countries. The total drop in output is relatively small in other countries: an 8.8 percent drop compared to a 30 percent drop in the United States. The international economies recovered quickly: output in almost all the countries returned to 1929 levels by 1935 and was well above those levels by 1938 . Employment also generally recovered to its 1929 level by $1938 .^{8}$

\section{Table 6. U.S. vs. international decline and recovery, 1932-38}

\begin{tabular}{lcc}
\hline Year & United States & $\begin{array}{c}\text { International } \\
\text { average }\end{array}$ \\
\hline 1932 & 70.0 & 91.2 \\
1933 & 67.1 & 94.5 \\
1935 & 80.6 & 100.9 \\
1938 & 87.5 & 112.4 \\
\hline
\end{tabular}

Source: Data from Maddison 1991.

Note: Data are normalized for each country so that per capita output is equal to 100 in 1929. International average includes Belgium, Britain, France, Germany, Italy, Japan, and Sweden.

We draw two conclusions from this comparison. First, the larger decline in the United States is consistent with the view that the shocks that caused the decline in the United States were larger than the shocks that caused the decline in the other countries. Second, the weak recovery in the United States was likely caused by a U.S. domestic shock rather than an international shock.

The data show that inputs and output in the United States fell considerably during the 1930s and did not recover much relative to the increase in productivity. Moreover, the decline was much more severe and the recovery much weaker in the United States than in other countries. To account for the 
decade-long Depression in the United States, we conclude that we should focus on domestic, rather than international, factors. We turn to this task in the next section.

\section{The Role of Real Shocks}

We first analyze three classes of real shocks considered important for understanding business cycle fluctuations: productivity shocks, fiscal policy shocks, and trade shocks.

\section{Productivity Shocks}

First we consider productivity shocks, defined as any exogenous factor that changes the efficiency with which business enterprises transform inputs into output. Under this broad definition, changes in productivity reflect not only true changes in technology and knowledge, but also other factors such as changes in work rules and practices or government regulations that affect the efficiency of production but are exogenous from the perspective of business enterprises. The key element that leads to a decline in economic activity in models with productivity shocks is a negative shock that reduces the marginal products of capital and labor. These negative shocks lead households to substitute out of market activities and into nonmarket activities, resulting in lower measured output. Recent research has identified these shocks as important factors in postwar business cycle fluctuations. Prescott (1986), for example, shows that a standard one-sector neoclassical model with a plausibly parameterized stochastic process for productivity shocks can account for 70 percent of postwar business cycle fluctuations. How much of the Great Depression can be accounted for by the negative productivity shocks of the early 1930s?

To address this question, we feed the actual productivity shocks into a real business cycle model and compute the time path of output from that model. (See Hansen 1985; Prescott 1986; or King, Plosser, and Rebelo 1988 for a discussion of this model.) Our model consists of equations (A1)-(A5) and (A9) in the appendix, along with the following four equations:

$$
u\left(c_{t}, l_{t}\right)=\log \left(c_{t}\right)+\phi \log \left(l_{t}\right) .
$$

We use the Cobb-Douglas production function specification:

$$
z_{t} f\left(k_{t}, n_{t}\right)=z_{t} k_{t}^{\theta}\left(x_{t} n_{t}\right)^{1-\theta} .
$$

The household has one unit of time available each period:

$$
1=l_{t}+n_{t}
$$


And we use the following specification of the stochastic process for the technology shock:

$$
z_{t}=(1-\rho)+\rho z_{t-1}+\varepsilon_{t}, \varepsilon_{t} \sim N\left(0, \sigma^{2}\right) .
$$

With parameter values, we use numerical methods to compute an approximate solution to the equilibrium of this economy. ${ }^{9}$ We set $\theta=0.33$ to conform to the observation that capital income is about one-third of output. We set $\sigma=$ 1.7 percent and $\rho=0.95^{4}$ to conform to the observed standard deviation and serial correlation of total factor productivity. We choose the value for the parameter $\phi$ so that households spend about one-third of their discretionary time working in the deterministic steady state. Labor-augmenting technological change $\left(x_{t}\right)$ grows at a rate of 1.9 percent per year. The population $\left(n_{t}\right)$ grows at a rate of 1 percent per year. We set the depreciation rate at 6 percent per year.

We conduct the analysis by assuming that the capital stock in 1929 is equal to its steady-state value, and then we feed in the sequence of observed levels of total factor productivity as measures of the technology shock. Given the initial condition and the time path of technology, the model generates labor input, output, consumption, and investment for each year during the 1930s. Figure 2 compares the detrended level of output from the model to the actual detrended level of output. The measured decrease in productivity between 1929 and 1933 generates a Depression in the model that is similar to the actual data: output in the model falls about 23 percent relative to trend in 1933, compared to the actual 38 percent decline. ${ }^{10}$ This similarity disappears after

\section{Figure 2. Actual and predicted output, 1929-39}

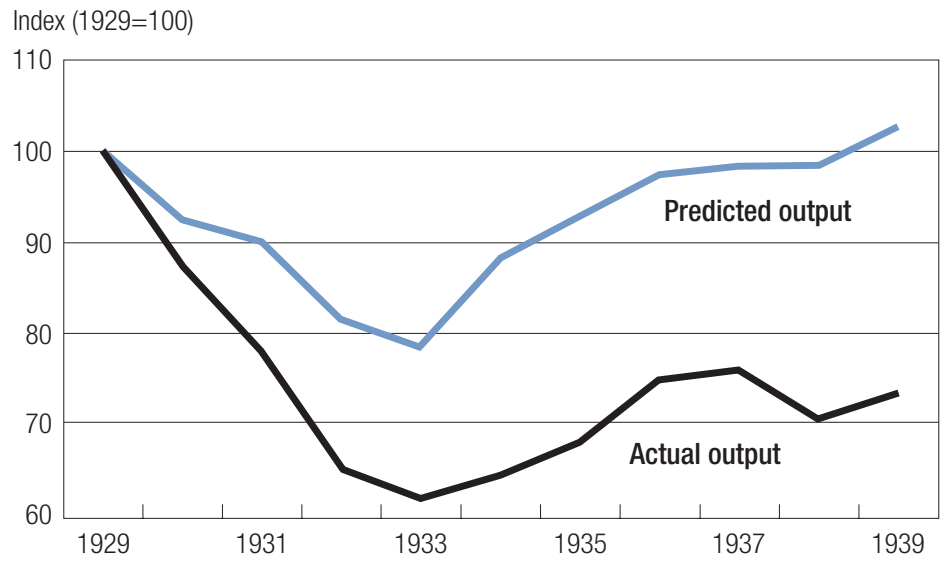


1933. As a consequence of rapid productivity growth, output in the model is almost back to its trend level by 1936. In contrast, actual output remained 25-30 percent below trend during the recovery. These findings suggest that productivity, or a productivity-related factor, may have played a role during the decline phase of the Great Depression, but that it cannot account for the weak recovery. ${ }^{11}$

A productivity explanation of the decline phase of the Great Depression is a very different way of thinking about this episode, and it is natural to ask whether these large negative productivity shocks are proxying for some other factor. One possibility is that these shocks are the consequence of capital and labor input mismeasurement, because total factor productivity change is defined residually as the percentage change in output minus a weighted average of the percentage change in inputs. Ohanian (2001) analyzes the quantitative implications of input mismeasurement and other possible factors affecting productivity measurement during the early 1930 s, and finds that these factors did not reverse the conclusion that there were big negative productivity shocks in the early 1930s. He corrects the productivity measure for changes in capital utilization, changes in the average quality of workers, changes in the composition of production across sectors, and increasing returns to scale. Ohanian finds that these factors can account for only about one-third of the measured decrease in productivity. The fact that a big productivity shock remains after these corrections suggests that some efficiency-related factor may have played a quantitatively significant role during the decline phase of the U.S. Great Depression.

We will focus the remainder of the paper around two questions. Can any of the other factors that we assess shed light on the large, negative productivity shocks between 1929 and 1933 ? Can they account for the puzzling weak recovery?

\section{Fiscal Policy Shocks}

We now consider fiscal policy shocks - changes in government purchases or tax rates. Christiano and Eichenbaum (1992) argue that government-purchase shocks are important in understanding postwar business cycle fluctuations, and Braun (1994) and McGrattan (1994) argue that shocks to distorting taxes have had significant effects on postwar cyclical activity.

Fluctuations in government spending can affect economic activity through income and substitution effects. A decrease in government spending will tend to increase private consumption and, consequently, lower the marginal rate of substitution between consumption and leisure, which will lead households to work less and take more leisure. Conversely, an increase in government purchases will tend to decrease private consumption and reduce the marginal 
rate of substitution between consumption and leisure. In this case, theory predicts that this will lead households to work more and take less leisure.

Historically, changes in government purchases have had large effects on economic activity. Ohanian (1997) shows that the increase in government purchases during World War II can account for much of the 60 percent increase in output during the 1940s. Can changes in government purchases also account for the decrease in output in the 1930s?

If government-purchase shocks were a key factor in the decline in employment and output in the 1930s, government purchases should have declined considerably during the period. This did not occur. Government purchases declined modestly between 1929 and 1933 and then rose sharply during the rest of the decade, rising about 12 percent above trend by 1939 . These data are inconsistent with the view that government-purchase shocks were a key factor in either the downturn or the weak recovery.

Although changes in government purchases are not important in accounting for the Depression, the way they were financed may be. Government purchases are largely financed by distorting taxes - taxes that affect the marginal conditions of households or firms. Most government revenue is raised by taxing factor incomes. Changes in factor income taxes change the net rental price of the factor. Increases in labor and capital income taxes reduce the returns to these factors and, thus, can lead households to substitute out of taxed activities by working and saving less.

If changes in factor income taxes were a key factor in the 1930s economy, these rates should have increased considerably in the 1930s. Tax rates on both labor and capital changed very little during 1929-33, which implies that they were not important for the decline. However, these rates rose during the rest of the decade. Joines (1981) calculates that between 1929 and 1939, the average marginal tax rate on labor income increased from 3.5 percent to 8.3 percent, and the average marginal tax rate on capital income increased from 29.5 percent to 42.5 percent. How much should these increases have depressed economic activity? To answer this question, we use the deterministic version of the model we used earlier to analyze the importance of technology shocks, and augment this model to allow for distortionary taxes on labor and capital income. We then compare the deterministic steady state of the model with 1939 tax rates to the deterministic steady state of the model with 1929 tax rates. With these differences in tax rates, we find that steady-state labor input falls by 4 percent. This suggests that higher taxes played a relatively minor role, accounting for less than 20 percent of the weak recovery.

Finally, neither government spending changes nor tax rate changes shed any light on the 1929-33 productivity decrease. This is because these fiscal changes are small during this period, and because there is no theoretical 
presumption that changes in government spending or tax rates change production efficiency.

\section{Trade Shocks}

Finally, we consider trade shocks. In the late 1920s and early 1930s, tariffs-domestic taxes on foreign goods - rose in the United States and in other countries. Tariffs raise the domestic price of foreign goods and, consequently, benefit domestic producers of goods that are substitutes for the taxed foreign goods. Higher tariffs almost certainly contributed to the 65 percent decline in world trade that occurred between 1929 and 1932. But how much did higher tariffs contribute to the decline in income and employment in the United States?

Probably very little, because trade was a very small fraction of U.S. output during that time. Imports and exports were both equal to about 5 percent of GNP, which led Lucas (1994) to conjecture that the quantitative effects of the world trade contraction during the 1930s are likely to have been "trivial." ${ }^{2}$ Crucini and Kahn (1996) quantify this factor in a model that plausibly maximized the impact of the trade shock on output. They model imports primarily as intermediate inputs, rather than as final goods, and they assume an elasticity of substitution between imported inputs and domestic inputs of two-thirds, which is below standard estimates between one and two (see Stern, Francis, and Schumacher 1976). Both of these modeling choices increase the impact of a trade disruption on output. Crucini and Kahn estimate that the tariff increases reduced output by only 2 percent between 1929 and 1933. Moreover, the importance of the trade factor likely declined over time as domestic producers increased production of previously imported inputs. We conclude that tariffs were not an important factor for either the decline phase or the weak recovery. We also conclude that the trade factor was too small to shed light on the 1929-33 productivity decline.

\section{The Role of Monetary Shocks}

Monetary shocks - unexpected changes in the stock of money-are considered an alternative and/or complementary factor to real shocks for understanding business cycles, and many economists argue that monetary shocks were a key factor in the 1929-33 decline. Much of the attraction to monetary shocks as a source of business cycles comes from the influential narrative monetary history of the United States by Friedman and Schwartz (1963), who present evidence that declines in the money supply tend to precede declines in nominal income. They also show that some measures of the money supply fell sharply during the 1929-33 decline. Friedman and Schwartz conclude from these data that the money supply decline was an important cause of the 1929-33 decline (contraction): 
The contraction is in fact a tragic testimonial to the importance of monetary forces. ... Prevention or moderation of the decline in the stock of money, let alone the substitution of monetary expansion, would have reduced the contraction's severity and almost as certainly its duration. (1963, 300-301)

\section{More Important in Decline than in Recovery}

We begin by presenting data on money, prices, and interest rates. Table 7 shows these data. The two measures of money are the monetary base (currency and reserves), which is the monetary aggregate controlled by the Federal Reserve; and M1, which is currency plus checkable deposits. The two interest rates are the average annual rate on three-month U.S. Treasury bills and the average annual rate on commercial paper. The money supply data are expressed in per capita terms by dividing by the working-age population and are also expressed relative to their 1929 values.

Table 7. Nominal money, prices, and interest rates, 1929-39

\begin{tabular}{ccrccc}
\hline & & & & \multicolumn{2}{c}{ Annual \% interest rate } \\
\cline { 3 - 6 } & $\begin{array}{c}\text { Monetary } \\
\text { base }\end{array}$ & M1 & Price level & $\begin{array}{c}\text { Three-month } \\
\text { T-bill }\end{array}$ & $\begin{array}{c}\text { Commercial } \\
\text { paper }\end{array}$ \\
\hline 1929 & 100.0 & 100.0 & 100.0 & 4.42 & 5.85 \\
1930 & 95.4 & 96.4 & 96.8 & 2.23 & 3.59 \\
1931 & 98.9 & 88.8 & 87.9 & 1.15 & 2.64 \\
1932 & 104.0 & 74.0 & 78.2 & 0.88 & 2.73 \\
1933 & 107.6 & 65.3 & 76.5 & 0.52 & 1.73 \\
1934 & 118.4 & 68.8 & 83.0 & 0.26 & 1.02 \\
1935 & 136.8 & 77.2 & 84.6 & 0.14 & 0.75 \\
1936 & 154.5 & 84.8 & 85.0 & 0.14 & 0.75 \\
1937 & 168.3 & 88.0 & 89.1 & 0.45 & 0.94 \\
1938 & 179.8 & 86.5 & 87.0 & 0.05 & 0.81 \\
1939 & 213.5 & 92.4 & 86.4 & 0.02 & 0.59 \\
\hline
\end{tabular}

These money supply data can be used to estimate the monetary shock. Estimating the shock requires choosing a monetary aggregate, then identifying the exogenous component of that aggregate, and then measuring the innovation to the exogenous component. The size of the monetary shock depends on the specific monetary aggregate, as M1 falls 35 percent between 1929 and 1933, while the monetary base grows during this period. We therefore report measures of the shock using both of these aggregates.

Table 8 shows estimates of the monetary shock using M1 and the base. The shock is the residual from an autoregressive forecasting model for the first difference of the log of each of the aggregates. The statistical model 
Table 8. Estimates of monetary shocks

\begin{tabular}{lrr}
\hline Year & M0 & \multicolumn{1}{c}{ M1 } \\
\hline 1930 & -0.05 & -0.05 \\
1931 & 0.05 & -0.10 \\
1932 & 0.00 & -0.18 \\
1933 & -0.01 & -0.08 \\
1934 & 0.07 & 0.05 \\
1935 & 0.07 & 0.04 \\
1936 & 0.02 & 0.01 \\
1937 & 0.02 & -0.02 \\
1938 & 0.02 & -0.05 \\
1939 & 0.13 & 0.05 \\
\hline
\end{tabular}

includes a constant and two lags. ${ }^{13}$ A caveat about the estimated M1 shocks is that this M1 has a large endogenous component (demand deposits) that is positively correlated with the level of general economic activity. Since our statistical model does not account for this endogenous component, estimating the shock using M1 will generate a shock that will tend to be too large in absolute value.

It is unlikely that monetary shocks kept the economy depressed after 1933. Most of the M1 shocks are positive after 1933, and all the monetary-base shocks are positive after this date. These post-1933 positive monetary shocks are the key reason why Lucas and Rapping (1972) find the weak recovery so puzzling. Their monetary business cycle model predicts that the economy should have fully recovered by 1936, rather than remaining 30 percent below trend. We agree with Lucas and Rapping that monetary shocks do not plausibly account for the weak recovery, and we focus instead on the role of monetary shocks for the downturn phase of the Depression. In 1929-33, the alternative measures of the monetary shock are quite different. The monetary-base shock is significantly negative only in 1930, and afterward is close to zero. In contrast, there are large negative M1 shocks during the downturn phase. As discussed above, however, the significant endogenous component in M1 raises questions about the size of this shock. In particular, these large negative shocks partially reflect the endogenous response of M1 to the decline in economic activity.

If monetary shocks were a key factor, understanding the impact of monetary shocks during the downturn requires specifying a channel of monetary nonneutrality. Imperfectly flexible wages are perhaps the most highly cited source of nonneutrality for the Depression (see Eichengreen and Sachs 1992; Bernanke and Carey 1996; and Bordo, Erceg, and Evans 1996). We have 
analyzed the sticky-wage hypothesis for 1929-33 in the United States and found that this factor contributed to the Great Depression but was not a major factor. This is because real wages were not particularly high, because this factor cannot account for the large negative productivity shocks observed during this period, and because there is no theory for understanding why wage stickiness would be so important after 1930. We summarize each of these in turn and conclude that if monetary shocks were important, their main effect came through some other channel.

Regarding real wages, Cole and Ohanian (2001) focus on manufacturing wages because these data are relatively high quality, and because President Hoover intervened in this sector to prevent nominal wage cuts. In particular, President Hoover jawboned the leaders of major manufacturing firms at a White House meeting in late 1929 to keep nominal wages fixed. Despite Hoover's intervention, which did have an impact on nominal wages very early in the Depression, the average manufacturing wage divided by the GNP deflator was only about 5 percent above trend, on average, during 1930-33. (Table 9 presents these data for 1930-39.) However, even this relatively small increase is biased upward because the average quality of employees rose during the Depression, as firms concentrated employment among the most experienced and productive workers. Firm-level evidence shows that this type of compositional change in employees generates quantitatively important

Table 9. Detrended real-wage rates $(1929=100)$

\begin{tabular}{lcrc}
\hline Year & Manufacturing & Total & Nonmanufacturing \\
\hline 1930 & 101.9 & 99.3 & 98.2 \\
1931 & 106.0 & 98.9 & 96.1 \\
1932 & 105.3 & 95.8 & 92.3 \\
1933 & 102.5 & 91.3 & 87.2 \\
1934 & 108.8 & 95.7 & 91.1 \\
1935 & 108.3 & 95.1 & 90.4 \\
1936 & 107.2 & 97.6 & 94.1 \\
1937 & 113.0 & 97.8 & 92.5 \\
1938 & 117.4 & 99.1 & 92.8 \\
1939 & 116.4 & 100.1 & 94.3 \\
\hline
\end{tabular}

upward bias in aggregate wage measures. For example, Westinghouse and General Electric, which comprised about 90 percent of the electrical equipment industry, cut wages by 10 percent between 1929 and 1931, laid off the least productive workers, and assigned the longest workweeks to the most productive workers. Despite these nominal wage cuts, this large composi- 
tional change in employees resulted in the average industry wage remaining unchanged during this period. Cole and Ohanian (2001) estimate the size of this compositional bias for aggregate wages and find that aggregate measured wages may be overstated by 15-18 percent at the trough of the Depression. Correcting the aggregate real wage for this bias implies that real wages were below normal, not above normal.

Another drawback to the sticky wage explanation is that its implication for labor productivity is strongly at variance with U.S. labor productivity. This is because contractionary money shocks raise labor productivity in this model, as firms move up their labor-demand curves to equate the higher real wage to the higher marginal product of labor. In contrast, actual labor productivity fell 15 percent between 1930 and 1933. This large discrepancy in labor productivity raises questions about the sticky wage explanation. ${ }^{14}$

A third drawback to the sticky wage explanation is that there is no theoretical framework for plausibly rationalizing persistently sticky nominal wages during the Depression. The usual factors that are cited for justifying sticky nominal wages were relatively unimportant during this period; there were no long-term nominal-wage contracts, and very few workers were members of independent labor unions. Given such limited union representation, it is hard to realistically justify how workers could have commanded such high wages during a period of negative profits, record business failures, and high unemployment. Monetary shocks remain a possibly important factor for 1929-33, but the evidence suggests that sticky wages probably are not the main channel.

\section{Financial Intermediation Shocks \\ Impact on the Downturn}

Banking is considered an important candidate shock because suspensions and failures of banks rose during the downturn. Establishing a significant role for banking in a quantitative equilibrium model remains a challenging task. Our review of recent work indicates that simple theories of intermediation show that banking shocks were a minor factor, and that there are several observations significantly at variance with banking as a major driving force of the Depression.

Several economists argue that the bank failures and temporary bank closings that occurred between 1930 and 1933 contributed to the severity of the decline phase of the Great Depression. Bernanke (1983) provides empirical support for this argument. He constructs a statistical model, based on Lucas and Rapping's (1969) model, in which unexpected changes in the money stock lead to changes in output. Bernanke (1983) shows that adding the dollar value of deposits and liabilities of failing and temporarily closed banks as 
explanatory variables significantly increases the fraction of output variation accounted for by the model. Bernanke and others suggest that these failures reduced the efficiency of intermediation by destroying local information capital that was specific to individual borrower-lender relationships.

Table 10 shows deposits as a fraction of nominal output that were in banks that either failed or temporarily suspended operations during the $1930 \mathrm{~s} .{ }^{15}$ On average, these deposits were about 2.5 percent of output during 1930-33. The absence of failures/suspensions after the adoption of federal deposit insurance in 1933 indicates that this was not a major factor for the weak recovery.

Table 10. Bank assets and liabilities relative to nominal output, 1929-39

\begin{tabular}{lccccc}
\hline \multicolumn{5}{c}{} & \multicolumn{3}{c}{ Relative to output } \\
\cline { 2 - 3 } & \multicolumn{2}{c}{ Deposits } & & & \\
\cline { 2 - 3 } Year & $\begin{array}{c}\text { Operating } \\
\text { banks }\end{array}$ & $\begin{array}{c}\text { Suspended } \\
\text { banks }\end{array}$ & Loans & $\begin{array}{c}\text { change } \\
\text { in loans }\end{array}$ & $\begin{array}{c}\text { Federal } \\
\text { securities }\end{array}$ \\
\hline 1929 & 0.57 & 0.00 & 0.40 & - & 0.05 \\
1930 & 0.62 & 0.01 & 0.44 & 11 & 0.06 \\
1931 & 0.62 & 0.02 & 0.46 & 4 & 0.09 \\
1932 & 0.76 & 0.01 & 0.47 & 3 & 0.12 \\
1933 & 0.68 & 0.06 & 0.39 & -17 & 0.14 \\
1934 & 0.75 & 0.00 & 0.32 & -18 & 0.17 \\
1935 & 0.75 & 0.00 & 0.27 & -15 & 0.19 \\
1936 & 0.72 & 0.00 & 0.25 & -11 & 0.21 \\
1937 & 0.63 & 0.00 & 0.24 & -1 & 0.18 \\
1938 & 0.71 & 0.00 & 0.24 & 0 & 0.21 \\
1939 & 0.74 & 0.00 & 0.23 & -5 & 0.21
\end{tabular}

Assessing the quantitative contribution of bank failures and suspensions requires a model that can address two questions: How big was the banking shock during 1930-33? How much did this shock reduce output in these years?

Cole and Ohanian (2000) developed a simple model that captures the view that failures and suspensions destroyed information capital. They model banking output as an intermediate input into the production of a single final good, and they assume that banking output was produced from a constant-returns-toscale Cobb-Douglas technology using bank deposits and information capital. In their model, there are a number of bank locations, and information capital is endowed to a specific location. They assume that new information capital cannot be created. This implies that deposits will be allocated across bank locations to equalize their marginal product. Aggregate banking output is then the sum of the outputs at all the bank locations. To maximize the impact of 
a banking shock, they assume that all of a bank's information capital is lost if the bank fails or if it temporarily suspended operations.

Their model implies that the fraction of information capital destroyedand the fraction of banking output destroyed during the Depression due to this factor-is equal to the cumulative fraction of deposits in failed or suspended banks during 1930-33. These cumulative figures for the four years are 1.7 percent, 6.0 percent, 8.0 percent, and 19.0 percent, respectively. ${ }^{16}$

How much did this reduction in banking output reduce GNP? Cole and Ohanian (2000) estimate this using a simple growth accounting analysis. With perfect competition, a first-order expansion of the production function implies that the percentage change in aggregate output, $\hat{y}$, is equal to the percentage change in the intermediate inputs $\left(\hat{y}_{i}\right)$, multiplied by their value-added shares $\left(\gamma_{i}\right)$. This first-order approximation is not specific to their environment, but rather holds in any model with perfect competition and a constant-returns-to-scale technology:

$$
\hat{y}=\sum_{i=1}^{n} \gamma_{i} \hat{y}_{i}
$$

The percentage of value added from the banking sector just prior to the Depression was about 1.5 percent. This implies that bank failures/suspensions reduced GNP by considerably less than 1 percent per year for each year.

This analysis indicates that bank failures and suspensions were not a major driving factor through the simple neoclassical channel of banking as an input to final goods production. An alternative possibility is that bank failures and suspensions were a major factor, but that this simple model does not have the mechanism that generates this effect. We now consider some possible factors that could increase the impact of failures/suspensions, but that are missing from the model. One possibility is that the first-order approximation is inaccurate because of very limited substitutability across the intermediate inputs. If this were true, then banking's share of value added should have increased substantially during the Great Depression. This did not happen. Its value-added share remained around 1 percent in 1933.

Another possibility is that an externality could have magnified this effect. Cole and Ohanian (2000) extend their local-information capital analysis to pursue this story by assuming that the quantity of information capital was a productive externality at the U.S. state level. Specifically, the output of a state is given by

$$
Y_{i t}=Z_{i t}^{\delta} F\left(K_{i t}, L_{i t}, \ldots\right)
$$


where $Z_{i t}$ is banking information capital in state $i$ at date $t$.

If banking were a key factor, then the states with the biggest fractions of deposits at suspended/failed banks should have had the biggest depressions. This did not happen. Figure 3 shows a scatterplot between the change in personal income during 1929-33 and the fraction of deposits in suspended/failed banks for each of the forty-eight states. There is no systematic relationship between these variables in the cross section; the correlation between suspended/failed deposits and personal income is only -.13 . The correlation between suspended/failed deposits and state-level manufacturing employment, which is an alternative measure of statewide economic activity, is also low (.12).

Figure 3. Personal income vs. suspensions by state during Depression

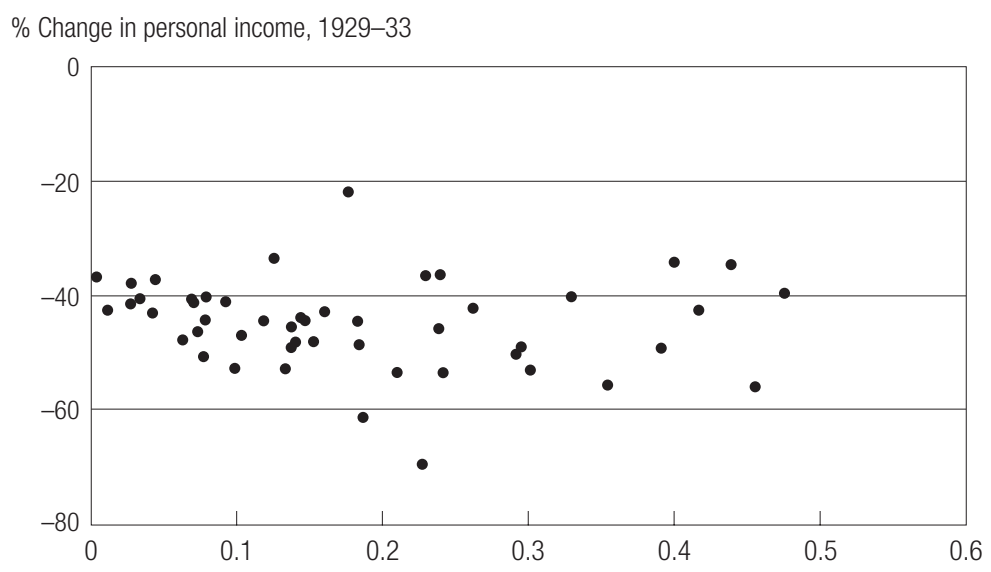

Commercial bank suspensions 1929-33 / total deposits, 1929

Cole and Ohanian (2000) also examine broader implications of shocks to financial intermediation by analyzing changes in the overall quantity of bank deposits and loans, changes in interest rate spreads, and changes in retained earnings. These data also raise questions about banking as a major depressing factor. We summarize each of these analyses in turn.

An alternative banking view of the Depression is that total banking services were in scarce supply not just because of failures and suspensions, but also because of exogenous deposit withdrawal at all banks. If exogenous withdrawals of deposits were a major factor, then the deposit-output ratio should have decreased during the Depression, reflecting the relative scarcity 
of deposits. This did not happen - this ratio rose from 0.59 in 1929 to 0.78 in 1932. Commercial and industrial loan data also support the view that banking services were not in relatively scarce supply during the Depression. Loans fell less than output between 1930 and 1932, and the stock of loans relative to GNP rose from 0.40 to 0.47 between 1929 and 1932. Additional evidence that banking capacity was not scarce is the behavior of bank holdings of federal securities. Bank holdings of federal securities rose from 5 percent of output in 1929 to 14 percent of output in 1933, and rose further to 21 percent in 1939 . These data suggest that banking capacity was not in relatively scarce supply in the 1930s.

Another possibility is that shocks to intermediation exogenously raised the spread between borrowing and lending rates, which contributed to the Depression by reducing borrowing. Assessing this view requires correcting the borrowing-lending spread for endogenous changes in default premia, which likely rose during the Depression. Cole and Ohanian (2000) address this issue by measuring the spread between borrowing and lending rates for securities with different default risk. The key implication of the theory is that if exogenously higher borrowing-lending spreads were a key factor driving the Depression, then we should observe large increases in the spread, irrespective to the quality of the security, and these increases should be much larger than those observed during post-World War II recessions.

This did not occur. First, the spread between borrowing rates and lending rates for high-quality borrowers changed very little during the Depression; the spread between the Aaa rate and the government bond rate (which they used as a proxy for the lending rate) rose from 113 basis points in 1929 to an average of 125 basis points in 1930-33. Second, the increase in the spread for high-default securities did not rise as much as it does during post-World War II recessions. The spread on Baa securities rose 194 basis points, increasing from 230 basis points in 1929 to an average of 424 basis points in 1930-33. This 194-basis-point increase is smaller than the average increase (over 200 basis points) in this spread that occurs during post-World War II recessions. Moreover, since the Depression was a period in which default probabilities were much higher than average, correcting the Depression spreads for this factor may generate a spread that is significantly lower than that during typical recessions.

The fact that spreads between risk-free and high-quality securities changed very little during the Depression, and the fact that on average, the increase in the spread between risk-free and low-quality securities during the Depression was smaller than during typical recessions, raise questions about the role of interest rate spreads as a major driving force behind the Depression.

Cole and Ohanian (2000) also examine how other variables should have 
changed if banking shocks were a major contributing factor, including the behavior of retained earnings, which are a very good substitute for intermediated funds. If banking shocks were a major driving factor behind the Depression, then firms should have increased their stock of retained earnings to substitute out of external finance and into internal finance, and to provide a buffer stock of cash. This did not happen. Figure 4 shows that retained earnings fell substantially during the Depression. They fell 50 percent in 1930 and were negative in 1931-33. Negative retained earnings means that firms were reducing their buffer cash reserves. If cash was so precious during the Depression because of negative banking shocks, why were firms eliminating their cash reserves?

\section{Figure 4. Domestic industries: Profits, dividends, retained earnings, 1929-39}

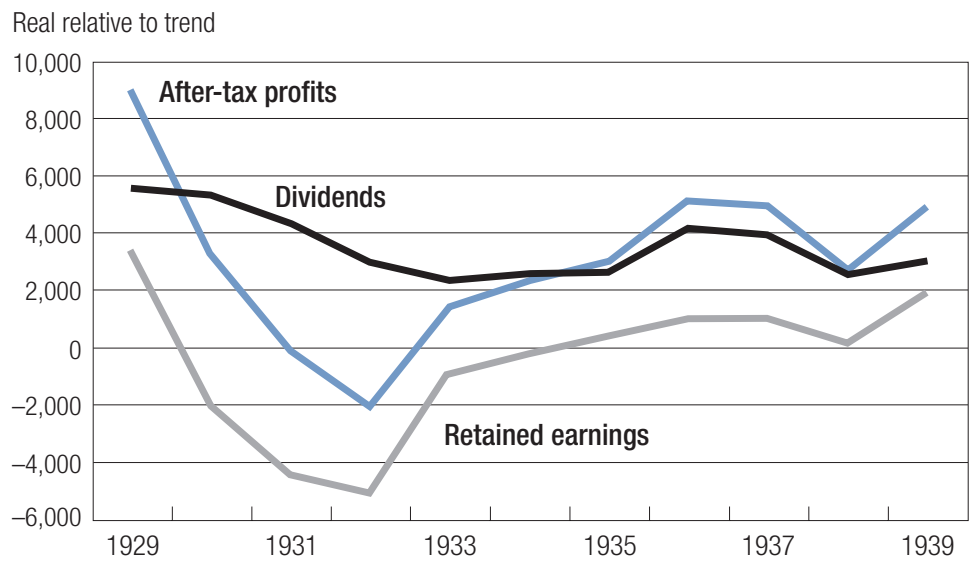

These observations highlight some of the challenges facing bankingdriven theories of the Depression. If banking was a key driving factor, then quantitatively assessing this factor requires a theoretical framework that can successfully account for these facts: there was no systematic relationship between the severity of the banking crisis and the level of depression in the cross section of the United States; the increase in borrowing-lending spreads during the Depression was no greater than the average increases observed in mild recessions; the deposit-output ratio and loan-output ratio both rose during the Depression; and corporate cash reserves fell significantly. We are unaware of any models that are consistent with these observations. Developing models that can confront these data is an important first step in the process of quantifying the contribution of banking shocks to the Depression, and should be pursued in future research. 


\section{Role in the Recovery}

We now consider whether intermediation shocks were an important factor behind the weak recovery. The introduction of federal deposit insurance largely eliminated banking panics after 1933. The leading intermediation shock for the recovery period in the literature is higher reserve requirements. In August 1936, the Federal Reserve increased the required fraction of net deposits that member banks must hold as reserves from 10 percent to 15 percent. This fraction rose to 17.5 percent in March 1937 and then rose to 20 percent in May 1937. Some economists, including Friedman and Schwartz (1963), argue that this factor contributed to weak macroeconomic performance during 1937 and 1938.

These economists argue that these policy changes increased bank reserves, which reduced lending and, consequently, reduced output. If this were true, we would expect to see output fall shortly after these changes. This did not happen. Between August 1936, when the first increase took place, and August 1937, industrial production rose about 12 percent. Industrial production did not begin falling until October 1937, which is fourteen months after the first and largest increase in reserve requirements. (Industrial production data are from the October 1943 Federal Reserve Index of Industrial Production of the Board of Governors of the Federal Reserve System.)

Another shortcoming of the reserve requirement view is that interest rates did not rise after these policy changes. Commercial loan rates fell from 2.74 percent in January 1936 to 2.65 percent in August 1936. These rates then fell to 2.57 percent in March 1937 and rose slightly to 2.64 percent in May 1937, the date of the last increase in reserve requirements. Lending rates then ranged between 2.48 percent and 2.60 percent over the rest of 1937 and through 1938. Interest rates on other securities showed similar patterns: rates on Aaa-, Aa-, and A-rated corporate debt were roughly unchanged between 1936 and $1938 .{ }^{17}$ (Interest rate data are from Banking and Monetary Statistics, 1914-1941, of the Board of Governors of the Federal Reserve System.) These data raise questions about the view that higher reserve requirements had important macroeconomic effects in the late 1930s.

\section{Diagnosing the Weak Recovery}

\section{A Big Distortion in the Labor Market}

Neoclassical theory indicates that the weak recovery from the Depression is a puzzle. We now use the theory to help identify candidate factors that kept the economy depressed after 1933. Cole and Ohanian (2002) and Chari, Kehoe, and McGrattan (2002) show how deviations in the first-order conditions can be used to diagnose depressions. ${ }^{18}$ 
Table 11 shows the four standard efficiency conditions for the competitive decentralization of our model with log utility over consumption and leisure. There are two equations for the household and two equations for a representative firm. In the table, $w$ denotes the wage rate, $r$ denotes the rental rate on capital, and $f_{n t}$ and $f_{k t}$ are the partial derivatives of the technology with respect to labor and capital. We refer to these conditions using $i=H, F$ for the household and the firm, and $j=L, K$ for labor and capital.

\section{Table 11. Efficiency conditions in the growth model}

\begin{tabular}{ccc}
\hline & Household & Firm \\
\hline Labor & $\psi /\left(1-n_{t}\right)=w_{t} / c_{t}$ & $w_{t}=f_{n t}$ \\
Capital & $1 / c_{t}=\beta\left(r_{t}+1-\delta\right) / c_{t+1}$ & $r_{t}=f_{k t}$
\end{tabular}

If the conditions hold, then the ratio of the left side of the conditions to the right side of the conditions is equal to one. We therefore form the ratio between the left and right sides of each of these equations, which we denote as $\phi_{i j t}$, and we parameterize the model for each country so that these conditions equal one prior to the Depression. We then measure these ratios during the Depression relative to their normal values.

These deviations provide clues to the factors that might account for these long depressions. For example, a household labor deviation suggests either that households could not satisfy this condition (e.g., an above-market wage that restricts trade in labor services) or that there is a difference between the wage and the actual return to work (e.g., taxes or subsidies). Similar reasoning applies to interpreting deviations in the household capital condition. Deviations in the firm labor and capital conditions suggest that these factors are not being compensated according to their marginal products, which could reflect changes in rent sharing and the distribution of income. While this discussion is not exhaustive, it does show how these deviations identify possible suspects for an initial investigation.

Table 12 shows the efficiency condition deviations for the United States in 1939 relative to $1929 .{ }^{19}$ The data show that three of the four conditions are distorted. The marginal rate of substitution (MRS) between consumption and leisure is 41 percent below the wage rate, and factor prices differ considerably from their implied marginal products. The wage rate substantially exceeds the marginal product of labor, and the return to capital is below the marginal product of capital. There is no deviation in the household's Euler equation, however. 
Table 12. Distortions in U.S. efficiency conditions: 1939 vs. 1929

\begin{tabular}{cccc}
\hline Household-Labor & Household-Capital & Firm-Labor & Firm-Capital \\
\hline 0.59 & 1.00 & 0.79 & 1.26 \\
\hline
\end{tabular}

We now document to what extent these deviations are accounted for by changes in quantities, as opposed to changes in factor prices. Table 13 therefore shows the wage rate divided by productivity in 1939, relative to this same ratio in 1929, and shows the difference in the real return to capital (in percentage points) between 1939 and 1929.

Table 13. Relative U.S. factor prices: 1939 vs. 1929

\begin{tabular}{cc}
\hline Real wage/TFP & Real return to capital (\%) \\
\hline 1.25 & 0.1 \\
\hline
\end{tabular}

Table 13 shows that the wage rate is 25 percent above its value implied by productivity growth, but that the return to capital is very close to its 1929 level. A high real wage during a period of depression is a puzzle. Why were more people not working, given the high real wage? Why was the real wage so high, given low consumption and labor? This suggests that some factor prevented normal competitive forces from equating the supply of labor to the demand for labor. Instead, these data indicate that some factor raised the wage above its market-clearing level, and that this high wage prevented households from satisfying their MRS condition.

\section{A Resolution of the Weak Recovery}

Cole and Ohanian (2004) argue that government labor and industrial policies are a key factor contributing to the weak recovery. Government policies toward monopoly changed considerably in the 1930s. In particular, the National Industrial Recovery Act of 1933 allowed much of the U.S. economy to cartelize. For over five hundred sectors, including manufacturing, antitrust law was suspended, and incumbent business leaders, in conjunction with government and labor representatives in each sector, drew up codes of fair competition. Many of these codes provided for minimum prices, output quotas, and open price systems in which all firms had to report current prices to the code authority and any price cut had to be filed in advance with the authority, who then notified other producers. Firms that attempted to cut prices were pressured by other industry members and publicly berated by the head of the National 
Recovery Administration as "cut-throat chiselers." In return for governmentsanctioned collusion, firms gave incumbent workers large pay increases and agreed to engage in collective bargaining with independent unions.

Cole and Ohanian (2004) present evidence showing that these policies increased relative prices and real wages by 25 percent or more in sectors that were effectively cartelized, and that the policies accounted for about 60 percent of the weak recovery in a conservatively parameterized model.

\section{Conclusions}

There are a number of fascinating questions and challenges about the Great Depression. One is developing models of negative productivity shocks for 1929-33. There were large decreases in TFP and labor productivity that do not seem to be fully accounted for by the usual suspects of capacity utilization and increasing returns. Clearly, an exogenous productivity-shock explanation of the Depression is unsatisfactory, as it simply pushes the question of what caused the Depression one step back. Thus, developing and testing models that can explain why productivity fell so much may advance our understanding of 1929-33, and may also have broader implications for understanding procyclical productivity during normal business cycle fluctuations. Another is developing alternative monetary models to the sticky-wage model — either as a model for why productivity fell or as a complementary factor to productivity. A third avenue is developing financial intermediation models that are consistent with the observations of no systematic relationship between the severity of the Depression and the severity of the banking crisis in the cross section, higher deposit-output and loan-output ratios, relatively small increases in borrowing-lending spreads, and large reductions in retained earnings.

Regarding the weak recovery, a remaining important puzzle is why the marginal product of capital was so much higher than the return to capital in the late 1930s. In Cole and Ohanian's (2004) model, capital is rented by firms on a competitive market and the real return is thus equated to the marginal product. We suspect that this large gap between the marginal product and the real return may be due to labor holding up sunk capital. This is because the late 1930s were the heyday of labor bargaining power, as the National Labor Relations Act of 1935 allowed workers to take a variety of actions against firms, including using the sit-down strike, in which workers forcibly occupied factories and prevented production. These strikes were effective in a number of major industries, including the auto and steel industries. Our current research is developing a dynamic equilibrium hold-up model along these lines. 


\section{The Recession of 1921: The Recovery Puzzle Deepens}

Many economists, including Friedman and Schwartz (1963), view the 1921 economic downturn as a classic monetary recession. Under this view, the 1921 recession and subsequent recovery support our view in this paper that the weak 1934-39 recovery is puzzling.

In 1921, the monetary base fell 9 percent, reflecting the Federal Reserve's policy of reducing the price level from its World War I peak. This decline is the largest one-year drop in the monetary base in the history of the United States. The price level did fall considerably, declining 18.5 percent in 1921. Real per capita output also fell in 1921, declining 3.4 percent relative to trend.

Since many economists assume that monetary factors were important in both the 1921 recession and the 1929-33 decline, we compare these two downturns and their recoveries in Tables 14 and 15. These tables show the price level normalized to 100 in the year before the downturn, as well as normalized detrended real per capita output.

Table 14. Price levels and detrended real output, 1921 recession

\begin{tabular}{ccc}
\hline Year & Price level & Real output \\
\hline 1921 & 85.2 & 93.9 \\
1922 & 80.6 & 96.2 \\
1923 & 82.8 & 104.8 \\
\hline
\end{tabular}

Table 15. Price levels and detrended real output, 1929-33 decline

\begin{tabular}{lcc}
\hline Year & Price level & Real output \\
\hline 1930 & 96.8 & 87.8 \\
1931 & 87.9 & 80.0 \\
1932 & 78.2 & 66.2 \\
1933 & 76.5 & 62.3 \\
1934 & 83.0 & 65.7 \\
1935 & 84.6 & 72.0 \\
1936 & 85.0 & 77.0 \\
1937 & 89.1 & 80.6 \\
1938 & 87.0 & 73.9 \\
1939 & 86.4 & 76.9 \\
\hline
\end{tabular}


There are two key differences between these periods. One is that the decrease in output relative to the decrease in the price level during the 1920 s is small compared to the decrease in output relative to the decrease in the price level that occurred during the 1930s. The 18.5 percent decrease in the price level in 1921 is more than five times as large as the 3.4 percent decrease in output in 1921. In contrast, the decrease in the price level is only about 62 percent of the average decrease in output between 1929 and 1933. The other difference is that the 1921 recession was followed by a fast recovery. Even before the price level ceased falling, the economy began to recover. Once the price level stabilized, the economy grew rapidly. Real per capita output was about 8 percent above trend by 1923, and private investment was nearly 70 percent above its 1921 level in 1923 . This pattern is qualitatively consistent with the predictions of monetary business cycle theory: a drop in output in response to the price level decline, followed immediately by a significant recovery.

In contrast, the end of the deflation after 1933 did not bring about a fast recovery after the 1929-33 decline. This comparison between these two declines and subsequent recoveries supports our view that weak post-1933 macroeconomic performance is difficult to understand. The recovery from the 1921 recession offers evidence that factors other than monetary shocks prevented a normal recovery from the 1929-33 decline. 


\section{Appendix: The Neoclassical Growth Model}

Here we describe the neoclassical growth model, which provides the theoretical framework in the preceding paper.

The neoclassical growth model has become the workhorse of macroeconomics, public finance, and international economics. The widespread use of this model in aggregate economics reflects its simplicity and the fact that its long-run predictions for output, consumption, investment, and shares of income paid to capital and labor conform closely to the long-run experience of the United States and other developed countries.

The model includes two constructs. One is a production function with constant returns to scale and smooth substitution possibilities between capital and labor inputs. Output is either consumed or saved to augment the capital stock. The other construct is a representative household which chooses a sequence of consumption, savings, and leisure to maximize the present discounted value of utility. ${ }^{20}$

The basic version of the model can be written as maximizing the lifetime utility of a representative household, which is endowed initially with $k_{0}$ units of capital and one unit of time at each date. Time can be used for work to produce goods $\left(n_{t}\right)$ or for leisure $\left(l_{t}\right)$. The objective function is maximized, subject to a sequence of constraints that require sufficient output $\left[f\left(k_{t}, n_{t}\right)\right]$ to finance the sum of consumption $\left(c_{t}\right)$ and investment $\left(i_{t}\right)$ at each date. Each unit of date $t$ output that is invested augments the date $t+1$ capital stock by one unit. The capital stock depreciates geometrically at rate $\delta$, and $\beta$ is the household's discount factor. Formally, the maximization problem is

(A1) $\max _{\left\{c_{t}, l_{t}\right\}} \sum_{t=0}^{\infty} \beta^{t} u\left(c_{t}, l_{t}\right)$,

subject to the following conditions:

(A3) $\quad i_{t}=k_{t+1}-(1-\delta) k_{t}$

(A4) $1=n_{t}+l_{t}$

(A5) $\quad c_{t} \geq 0, n_{t} \geq 0, k_{t+1} \geq 0$.

Under standard conditions, an interior optimum exists for this problem. (See Stokey, Lucas, and Prescott 1989.) The optimal quantities satisfy the following two first-order conditions at each date:

$$
u_{l_{t}}=u_{c_{t}} f_{2}\left(k_{t}, n_{t}\right)
$$




$$
u_{c_{t}}=\beta u_{c_{t+1}}\left[f_{1}\left(k_{t+1}, n_{t+1}\right)+(1-\delta)\right]
$$

Equation (A6) characterizes the trade-off between taking leisure and working by equating the marginal utility of leisure, $u_{l_{t}}$, to the marginal benefit of working, which is working one additional unit and consuming the proceeds: $u_{c_{t}} f_{2}\left(k_{t}, n_{t}\right)$. Equation (A7) characterizes the trade-off between consuming one additional unit today and investing that unit and consuming the proceeds tomorrow. This trade-off involves equating the marginal utility of consumption today, $u_{c_{t}}$, to the discounted marginal utility of consumption tomorrow and multiplying by the marginal product of capital tomorrow. This version of the model has a steady state in which all variables converge to constants. To introduce steady-state growth into this model, the production technology is modified to include labor-augmenting technological change, $x_{t}$ :

$$
x_{t+1}=(1+\gamma) x_{t},
$$

where the variable $x_{t}$ represents the efficiency of labor input, which is assumed to grow at the constant rate $\gamma$ over time. The production function is modified to be $f\left(k_{t}, x_{t} n_{t}\right)$. King, Plosser, and Rebelo (1988) show that relative to trend growth, this version of the model has a steady state and has the same characteristics as the model without growth.

This very simple framework, featuring intertemporal optimization, capital accumulation, and an aggregate production function, is the foundation of many modern business cycle models. For example, models with technology shocks start with this framework and add a stochastic disturbance to the production technology. In this case, the resource constraint becomes

$$
z_{t} f\left(k_{t}, n_{t}\right) \geq c_{t}+i_{t},
$$

where $z_{t}$ is a random variable that shifts the production function. Fluctuations in the technology shock affect the marginal products of capital and labor and, consequently, lead to fluctuations in allocations and relative prices. (See Prescott 1986 for details.)

Models with government spending shocks start with the basic framework and add stochastic government purchases. In this case, the resource constraint is modified as follows:

$$
f\left(k_{t}, n_{t}\right) \geq c_{t}+i_{t}+g_{t},
$$

where $g_{t}$ is stochastic government purchases. An increase in government purchases reduces output available for private use. This reduction in private resources makes households poorer and leads them to work more. (See Christiano and Eichenbaum 1992 and Baxter and King 1993 for details.)

Because these economies do not have distortions, such as distorting taxes or money, the allocations obtained as the solution to the maximization problem are also 
competitive equilibrium allocations. (See Stokey, Lucas, and Prescott 1989.) The solution to the optimization problem can be interpreted as the competitive equilibrium of an economy with a large number of identical consumers, all of whom start with $k_{0}$ units of capital, and a large number of firms, all of which have access to the technology $f(k, n)$ for transforming inputs into output. The equilibrium consists of rental prices for capital, $r_{t}=f_{1}\left(k_{t}, n_{t}\right)$; labor costs, $w_{t}=f_{2}\left(k_{t}, n_{t}\right)$; and the quantities of consumption, labor, and investment at each date $t=0, \ldots, \infty$. In this economy, the representative consumer's budget constraint is given by

(A11) $r_{t} k_{t}+w_{t} n_{t} \geq c_{t}+i_{t}$

The consumer's objective is to maximize the value of discounted utility subject to the consumer's budget constraint and the transition rule for capital (A3). The firm's objective is to maximize the value of profits at each date. Profits are given by

(A12) $f\left(k_{t}, n_{t}\right)-r_{t} k_{t}-w_{t} n_{t}$.

The effects of monetary disturbances can also be studied in the neoclassical growth framework by introducing money into the model. The introduction of money, however, represents a distortion; consequently, the competitive equilibrium will not generally coincide with the solution to the optimization problem. (See Stokey, Lucas, and Prescott 1989.) In this case, the equations for the competitive equilibrium, rather than the optimization problem, are used in the analysis.

One widely used approach to adding money to the equilibrium model is to introduce a cash-in-advance constraint, which requires that consumption be purchased with cash:

(A13) $m_{t} \geq p_{t} c_{t}$

where $m_{t}$ is the money supply and $p_{t}$ is the price (in dollars) of the physical good. In this model, changes in the money stock affect expected inflation, which, in turn, changes households' incentives to work and thus leads to fluctuations in labor input. (See Cooley and Hansen 1989 for details.) More complex monetary models, including models with imperfectly flexible prices or wages or imperfect information about the stock of money, also use the basic model as a foundation.

\section{Notes}

Originally published in a slightly different form in Federal Reserve Bank of Minneapolis Quarterly Review, Vol. 23, Harold L. Cole and Lee E. Ohanian, "The Great Depression in the United States from a Neoclassical Perspective," pages 2-24, copyright 1999.

We appreciate helpful comments from many colleagues over the six years this paper circulated in various forms. We particularly thank Bob Lucas, Tom Sargent, and Edward Prescott. Ed deserves special thanks for many discussions about depressions, as well as originally pos- 
ing the challenge that the Great Depression defied a neoclassical explanation. We also thank Simona Cociuba, Jesus Villaverde, Keisuke Otsu, and Mauro Rodrigues for excellent research assistance at different stages of the project. Finally, we thank the National Science Foundation for its support.

1. For other studies of the Depression and many additional references, see Bernanke 1983, 1995; Brunner 1981; Temin 1989, 1993; Eichengreen 1992; Calomiris 1993; Margo 1993; Romer 1993; Bordo, Erceg, and Evans 1996; and Crucini and Kahn 1996.

2. Note that in the closed economy framework of the neoclassical growth model, savings equals investment.

3. We end our analysis in 1939 to avoid the effects of World War II.

4. We make the trend adjustment by dividing each variable by its long-run trend growth rate relative to the reference date. For example, we divide GNP in 1930 by 1.019. This number is one plus the average growth rate of 1.9 percent over the 1947-97 period and over the 1919-29 period. For 1931, we divide the variable by $1.019^{2}$, and so forth.

5. To obtain this measure, we divide per capita output in 1939 by per capita output in 1929 (0.89) and divide the result by $1.019^{10}$.

6. This point is first stressed in Hall 1978.

7. Hours will be constant along the steady-state growth path if preferences and technology satisfy certain properties. See King, Plosser, and Rebelo 1988.

8. The average ratio of employment in 1939 to employment in 1929 was one in these countries, indicating that employment had recovered.

9. We used Marcet's parameterized expectations procedure.

10. In our earlier paper (Cole and Ohanian 1999) we conducted a similar exercise and reported that productivity shocks reduced output by about 15 percent. This was a typographical error.

11. Some economists have argued that capital's share of output is larger than one-third, based on unmeasured capital such as organizational capital and human capital. We also conducted the analysis using a model with a two-thirds capital share. The predicted recovery was also much faster in this model, with output recovering to 95 percent of trend by 1939 .

12. To understand why a trade disruption would have such a small effect on output in a country with a small trade share, consider the following example. Assume that final goods are produced with both domestic $(Z)$ and foreign $(M)$ intermediate goods and that the prices of all goods are normalized to one. Assuming an elasticity of substitution between home and foreign goods of one implies that the production for final goods, $Y$, is Cobb-Douglas, or

$$
Y=Z^{\alpha} M^{1-\alpha},
$$

where $\alpha$ is the share parameter for intermediate inputs. This assumption implies that with the level of domestic intermediate goods held fixed,

$$
\% \Delta Y=(1-\alpha) \% \Delta M \text {. }
$$

The fact that U.S. imports were 4 percent of total output and U.S. exports 5 percent in 1929 suggests that the highest the cost share of inputs in production could have been was $0.04 / 0.95 \simeq 0.04$. Hence, an extreme disruption in trade that led to an 80 percent drop in imports would lead to only a 3.2 percent drop in output. (See Crucini and Kahn 1996 for more on this issue.) 
13. We experimented with a variety of models and found the results to be robust to plausible variations in the model.

14. Note that the sticky-wage model, augmented with variable capacity utilization, cannot account for lower labor productivity. This model generates higher labor productivity in response to unexpected deflation.

15. The data do not distinguish between banks that failed versus banks that temporarily suspended operations.

16. Note that this measure of suspended deposits (as a fraction of total deposits) differs from that in Table 10.

17. Interest rates on Baa debt, which is considered by investment bankers to have higher default risk than these other debts, did begin to rise in late 1937 and 1938.

18. A number of other economists (see, e.g., Parkin 1984; Hall 1987; Ingram, Kocherlakota, and Savin 1997; Mulligan 2000) have also used subsets of the conditions we examine in their analyses of the household's static first-order condition that equates the marginal rate of substitution between consumption and leisure to the wage.

19. The data are taken from Cole and Ohanian 1999. The wage is the manufacturing wage from Hanes 1996, divided by the GNP deflator. The capital stock is real equipment and structures for the corporate sector. Hours worked are from Kendrick 1961. The gross return to capital is corporate profits relative to the corporate capital stock, deflated by the GNP deflator. We use a 5 percent depreciation rate, which is the historical rate for the corporate capital stock during this period.

20. Solow's (1956) original version of this model features a representative agent who inelastically supplies one unit of labor and who consumes and saves a fixed fraction of output. Cass (1965) and Koopmans (1965) replace the fixed savings formulation of Solow with an optimizing representative consumer.

\section{References}

Baxter, Marianne, and Robert G. King. 1993. Fiscal policy in general equilibrium. American Economic Review 83 (June): 315-34.

Bernanke, Ben S. 1983. Nonmonetary effects of the financial crisis in propagation of the Great Depression. American Economic Review 73 (June): 257-76.

- 1995. The macroeconomics of the Great Depression: A comparative approach. Journal of Money, Credit and Banking 27 (February): 1-28.

Bernanke, Ben S., and Kevin Carey. 1996. Nominal wage stickiness and aggregate supply in the Great Depression. Quarterly Journal of Economics 111 (August): 853-83.

Bordo, Michael D.; Christopher I. Erceg; and Charles L. Evans. 1996. Money, sticky wages, and the Great Depression. Discussion Paper. Rutgers University.

Braun, R. Anton. 1994. Tax disturbances and real economic activity in the postwar United States. Journal of Monetary Economics 33 (June): 441-62. 
Brunner, Karl, ed. 1981. The Great Depression revisited. Rochester Studies in Economics and Policy Issues, Vol. 2. Boston: Martinus Nijhoff.

Calomiris, Charles W. 1993. Financial factors in the Great Depression. Journal of Economic Perspectives 7 (Spring): 61-85.

Cass, David. 1965. Optimum growth in an aggregative model of capital accumulation. Review of Economic Studies 37 (July): 233-40.

Chari, V.V.; Patrick J. Kehoe; and Ellen R. McGrattan. 2002. Accounting for the Great Depression. American Economic Review 92 (May): 22-28.

Christiano, Lawrence J., and Martin Eichenbaum. 1992. Current real-business-cycle theories and aggregate labor-market fluctuations. American Economic Review 82 (June): $430-50$.

Cole, Harold L., and Lee E. Ohanian. 1999. The Great Depression in the United States from a neoclassical perspective. Federal Reserve Bank of Minneapolis Quarterly Review 23 (Winter): 2-24.

2001. Re-examining the contributions of money and banking shocks to the U.S. Great Depression. In NBER Macroeconomics Annual 2000, ed. Ben S. Bernanke and Kenneth S. Rogoff. Cambridge, MA: MIT Press.

2002. The U.S. and U.K. Great Depressions through the lens of neoclassical growth theory. American Economic Review 92 (May): 28-32.

2004. New Deal policies and the persistence of the Great Depression: A general equilibrium analysis. Journal of Political Economy 112 (August): 779-817.

Cooley, Thomas F., and Gary D. Hansen. 1989. The inflation tax in a real business cycle model. American Economic Review 79 (September): 733-48.

Crucini, Mario J., and James Kahn. 1996. Tariffs and aggregate economic activity: Lessons from the Great Depression. Journal of Monetary Economics 38 (December): 427-67.

Eichengreen, Barry. 1992. Golden fetters: The gold standard and the Great Depression, 1919-1939. NBER Series on Long-Term Factors in Economic Development. Oxford: Oxford University Press.

Eichengreen, Barry, and Jeffrey Sachs. 1992. Exchange rates and economic recovery in the 1930s. Journal of Economic History 45 (December): 925-46.

Friedman, Milton, and Anna J. Schwartz. 1963. A monetary history of the United States, 1867-1960. Princeton, NJ: Princeton University Press (for NBER).

Hall, Robert E. 1978. Stochastic implications of the life cycle-permanent income hypothesis: Theory and evidence. Journal of Political Economy 86 (December): 971-87.

. 1997. Macroeconomic fluctuations and the allocation of time. Journal of Labor Economics 15 (January): S223-50.

Hanes, Christopher. 1996. Changes in the cyclical behavior of real wage rates, 1870-1990. Journal of Economic History 56 (December): 837-61.

Hansen, Gary D. 1985. Indivisible labor and the business cycle. Journal of Monetary Economics 16 (November): 309-27.

Hodrick, Robert J., and Edward C. Prescott. 1997. Postwar U.S. business cycles: An empirical investigation. Journal of Money, Credit and Banking (Ohio State University Press) 29 (1): $1-16$. 
Ingram, Beth F.; Narayana R. Kocherlakota; and N. E. Savin. 1997. Using theory for measurement: An analysis of the cyclical behavior of home production. Journal of Monetary Economics 40 (3): 435-56.

Joines, Douglas H. 1981. Estimates of effective marginal tax rates on factor incomes. Journal of Business 54 (April): 191-226.

Kendrick, John W. 1961. Productivity trends in the United States. Princeton, NJ: Princeton University Press (for NBER).

King, Robert G.; Charles I. Plosser; and Sergio T. Rebelo. 1988. Production, growth and business cycles: I. The basic neoclassical model. Journal of Monetary Economics 21 (March-May): 195-232.

Koopmans, Tjalling C. 1965. On the concept of economic growth. In The econometric approach to development planning. Chicago: Rand-McNally.

Kydland, Finn E., and Edward C. Prescott. 1982. Time to build and aggregate fluctuations. Econometrica 50 (November): 1345-70.

Lucas, Robert E., Jr. 1994. Review of Milton Friedman and Anna J. Schwartz's A monetary history of the United States, 1867-1960. Journal of Monetary Economics 34 (August): 5-16.

Lucas, Robert E., Jr., and Leonard A. Rapping. 1969. Real wages, employment, and inflation. Journal of Political Economy 77 (September-October): 721-54.

- 1972. Unemployment in the Great Depression: Is there a full explanation? Journal of Political Economy 80 (January-February): 186-91.

Maddison, Angus. 1991. Dynamic forces in capitalist development: A long-run comparative view. Oxford: Oxford University Press.

Margo, Robert A. 1993. Employment and unemployment in the 1930s. Journal of Economic Perspectives 7 (Spring): 41-59.

McGrattan, Ellen R. 1994. The macroeconomic effects of distortionary taxation. Journal of Monetary Economics 33 (June): 573-601.

Mulligan, Casey. 2000. A century of labor-leisure distortions. Discussion paper. University of Chicago.

Ohanian, Lee E. 1997. The macroeconomic effects of war finance in the United States: World War II and the Korean War. American Economic Review 87 (March): 23-40. . 2001. Why did productivity fall so much during the Great Depression? American Economic Review 91 (May): 34-38.

Parkin, Michael. 1988. A method for determining whether parameters in aggregative models are structural. Carnegie-Rochester Conference Series on Public Policy 29 (Autumn): $215-57$.

Prescott, Edward C. 1986. Theory ahead of business cycle measurement. Federal Reserve Bank of Minneapolis Quarterly Review 10 (Fall): 9-22.

Romer, Christina D. 1993. The nation in depression. Journal of Economic Perspectives 7 (Spring): 19-39.

Solow, Robert M. 1956. A contribution to the theory of economic growth. Quarterly Journal of Economics 70 (February): 65-94. 
Great U.S. Depression

Cole, Ohanian

Stern, Robert; Jonathan Francis; and Bruce Schumacher. 1976. Price elasticities in international trade: An annotated bibliography. London: Macmillan.

Stokey, Nancy L.; Robert E. Lucas Jr.; and Edward C. Prescott. 1989. Recursive methods in economic dynamics. Cambridge, MA: Harvard University Press.

Temin, Peter. 1989. Lessons from the Great Depression. Lionel Robbins Lectures. Cambridge, MA: MIT Press.

1993. Transmission of the Great Depression. Journal of Economic Perspectives 7 (Spring): 87-102.

U.S. Department of Commerce. Bureau of Economic Analysis. Various dates (see Data Appendix). National income and product accounts. 
